\title{
Modelling of wind power plants operation
}

\author{
Ján Tkáč, Marek Hvizdoš, Jozef Rusnák \\ Department of Electric Power Engineering \\ Faculty of Electrical Engineering and Informatics, Technical university of Košice \\ Košice, Slovakia \\ jan.tkac@tuke.sk,marek.hvizdos@tuke.sk,jozef.rusnak@tuke.sk
}

\begin{abstract}
This article is oriented in the area of wind power plant operation modelling. Installed power of wind power plants reached $120 \mathrm{GW}$ in year 2009. Interest of investors in wind power plants installing is still very intensive. Electric power systems are not adapted for this situation because these sources are dispersed. Therefore it is necessary to exam their impact on systems before their connection to the network. The article presents a brief description of possibilities of modelling of DFIG-based wind power plants in EUROSTAG software in case of network short circuits.
\end{abstract}

\section{Keywords-wind power plant; modelling; EUROSTAG}

\section{INTRODUCTION}

Through the human history people have harnessed the wind. Wind is the important source of energy. Exhaustible energy of air mass flow is approximately 500 times bigger than power of all power station in the world. Today it is used only small part of this energy. Transformation from the wind kinetic energy to the mechanic energy was known in $1^{\text {st }}$ century. However, in Europe, the wind mills were used from $10^{\text {th }}$ century. An air circulation is developed because of unbalanced air heating by solar radiation. The air flows horizontally considering the earth surface. The air motion is characterised by direction and by velocity. Wind turbines use mainly the wind of velocity in range $5-13 \mathrm{~m} / \mathrm{s}$. They are disconnected from a network at a velocity exceeding $24 \mathrm{~m} / \mathrm{s}$. Wind speed has important impact on output power of wind power plants according to the following formula

$$
P_{\mathrm{e}} \approx 0.2 \cdot D^{2} \cdot v^{3} .
$$

The power of wind turbine $P_{\mathrm{e}}(\mathrm{W})$ depends on square of rotor diameter $D(\mathrm{~m})$ and on cube of wind velocity $v(\mathrm{~m} / \mathrm{s})$. The wind velocity decrease by $1 \mathrm{~m} / \mathrm{s}$ requires the diameter increase to $(1.5-2) \cdot D$ to keep the same level of the power. For the successful wind energy utilisation, it is the most important to choose suitable locality with small direct and speed variability and with a sufficient amount of hours per year with necessary velocity.

According to increasing of a number of wind power plants a fear from their negative impact on Electric Power System (EPS) operation exists. Therefore it is necessary to deal with operational problems of these sources in advance of their installation to EPS. For this purpose it is useful to use different simulation tools. There are many software packages capable to solve demanding power engineering problems [1], [2], [3], [4].
The possibilities of wind power plants modelling in EUROSTAG software are mentioned in this article.

\section{DFIG-BASED WIND POWER Plants MODELLING}

Wind power plants are dividing according to rotation axis of rotor into horizontal and vertical wind power plants. The most used ones are wind power plants with horizontal axis.

Main types of wind turbines with horizontal axis according to the technology are wind turbines with asynchronous generator with short-circuit armature, DFIG-based wind turbines and synchronous-based wind turbines. The most modern wind power plants with horizontal axis are DFIG-based wind power plants.

The model of the doubly fed induction generator (DFIG) is composed of the following different parts:

- Model of the doubly-fed machine and the converters;

- Aerodynamic model of the wind blades;

- Model of the wind turbine control (Pitch controller, Power controller and Main controller).

DFIG is an induction generator where the rotor windings are not short-circuited, and are connected through a back to back power electronics converter to the machine terminals (to the network). The converter controls the rotor speed and the reactive power injected on the network.

Rotor speed are able to change until $30 \%$ around a synchronous speed and so to adapt on characteristic of wind turbine and so to increase an active power delivered into a network (according to [5] approximately about $5 \%$ ).

In the case of voltage dip a machine's behaviour depends on its construction. The most perfect applications are able to be disconnected from the network.

General control scheme of DFIG-based wind power plant is presented in Fig. 1.

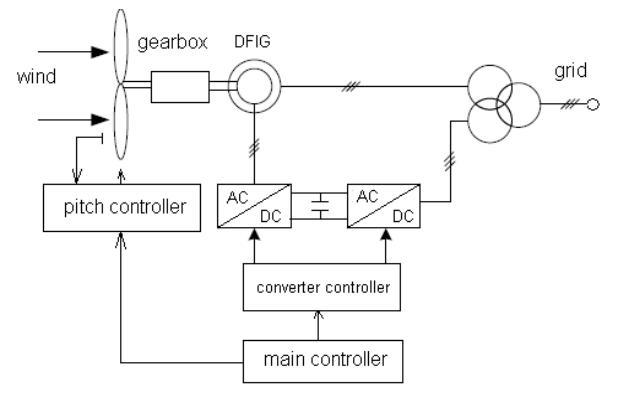

Figure 1. General control scheme of DFIG-based wind power plant 
The control functions are divided into 3 blocks called Main Controller, Pitch Controller and Power Controller.

The main controller manages the overall control functions, whereas pitch and power controller are subordinate units. The objective is to determine the optimal values of the WT speed and the pitch angle for a given wind speed in order to maximize the electrical power produced.

There are two main operating modes:

- When the wind speed is below a certain threshold, the turbine is not able to produce the rated power. In this case, the partial Load Controller is activated. It controls the turbine speed, for maximizing the produced power.

- When the wind speed is above the rated value, the full Load Controller is activated. It controls the pitch angle limiting the produced power to the rated value.

Software's package is able to model and to visualise behaviour of EPS from a moment of fault occurred in a system to a moment of fault clearing (software uses so-called a conception of generalised stability). Conception of generalised stability covers a frequency range from $0,001 \mathrm{~Hz}$ to $10 \mathrm{~Hz}$ (from rotor's transient states to slow thermal states of boilers or slow states of central control units) [1].

EUROSTAG enables to study a large-scale power system over long periods with no modelling changes. Typical examples of these are: finding the critical clearing time, checking the keeping up of synchronism after various disturbances, strategies for automatic load-shedding, contingency analysis under abnormal operating conditions (preventive security), behaviour of the power system in emergency or in extreme conditions (voltage collapse, loss of synchronism, resynchronization, etc.), dynamic stability of the machines, regulations, transmission system around an operating point of the power system, design and tuning of the local control systems (Speed governors, AVR, transformer tap controllers, ...), design, co-ordination and adjustment of protection systems for power plants and transmission networks, design of centralized control and protection systems, opportunity studies on different technologies, analysis of the behaviour of industrial systems [2].

The structure and the links between the macroblocks of the DFIG model in EUROSTAG are shown in Fig. 2.

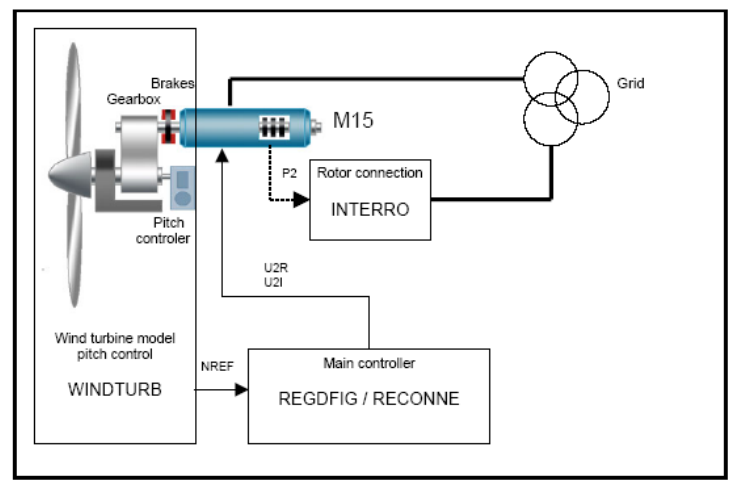

Figure 2. Links between the macroblocks of the DFIG model in EUROSTAG [2]
Model of the wind power plant consists of the model DFIG (,M15“), the model of current's injector and so-called macroblocks WINDTURB, REGDFIG, RECONNE and INTERRO.

The macroblock WINDTURB calculates the mechanical torque $(\mathrm{CM})$ and the optimal rotor speed based on the actual wind speed given by user (@VENT). The reference rotor speed NREF is transmitted to the macroblock REGDFIG.

The macroblock REGDFIG calculates the rotor voltages (U2R and U2I) to control the rotor currents and calculates the rotor active power (P2) based on NREF and actual rotor speed.

The macroblock RECONNE manages the operation of the induction machine while the stator is disconnected in case of disturbance on the network. The rotor voltage regulation is then carried out in the macroblock RECONNE and the calculated values are used in REGDFIG. The stator opening and reclosing is managed by an automaton (DFIG stator protection).

The macroblock INTERRO controls the injector WT_GSC and models the grid side converter. The value of the active power generated by the rotor (P2) is transmitted to INTERRO via a parameterized interface variable. So WT_STAT and WT_GSC are coupled.

\section{MODELLING OF COOPERATION OF WIND POWER PLANTS WITH EPS}

There are 2 wind power plants operated in the EPS (Fig. 3).

Each of them has rated active power $20 \mathrm{MW}$. Each power plant consists of 10 DFIG-based wind turbines with rated power 2 MW. The model of each wind power plant is represented by comprehensive asynchronous generator WT_STAT and by comprehensive exciter WT_GSC which are interconnected with three-winding transformer WT. This transformer represents all three-winding transformers which are a part of DFIG-based wind power plant. Therefore EUROSTAG take into account two wind power plants (WT_STAT1 with $20 \mathrm{MW}$ and WT STAT2 with 20MW). Next parts of the electric power system are generator with rated active power $220 \mathrm{MW}$ and nominal voltage $15,75 \mathrm{kV}$, transformer T1 $(15,75 \mathrm{kV} / 400 \mathrm{kV})$ and transformer T2 $(400 \mathrm{kV} / 110 \mathrm{kV})$, power lines $185 \mathrm{AlFe} 6$ (NHV1-NHV2 and NHV2-NHV3 with length $20 \mathrm{~km}$ and NHV2-NLOAD1 and NHV2-NLOAD2 with length $10 \mathrm{~km}$ ) and loads at the nodes NHV1 (200 MW, 60 MVAr) and NHV3 (20 MW, 6 MVAr).

Various operation conditions including network short circuits were examined. They were described in [6].

The following part describes a response of EPS and wind power plant to network short circuits in detail.

Three-phase short circuit on transmission power line NHV2 - NHV1 (1) close to node NHV2 occurred in time $101 \mathrm{~s}$. After $100 \mathrm{~ms}$ the transmission power line was disconnected by line protection device. Three different cases were simulated in EUROSTAG software. 


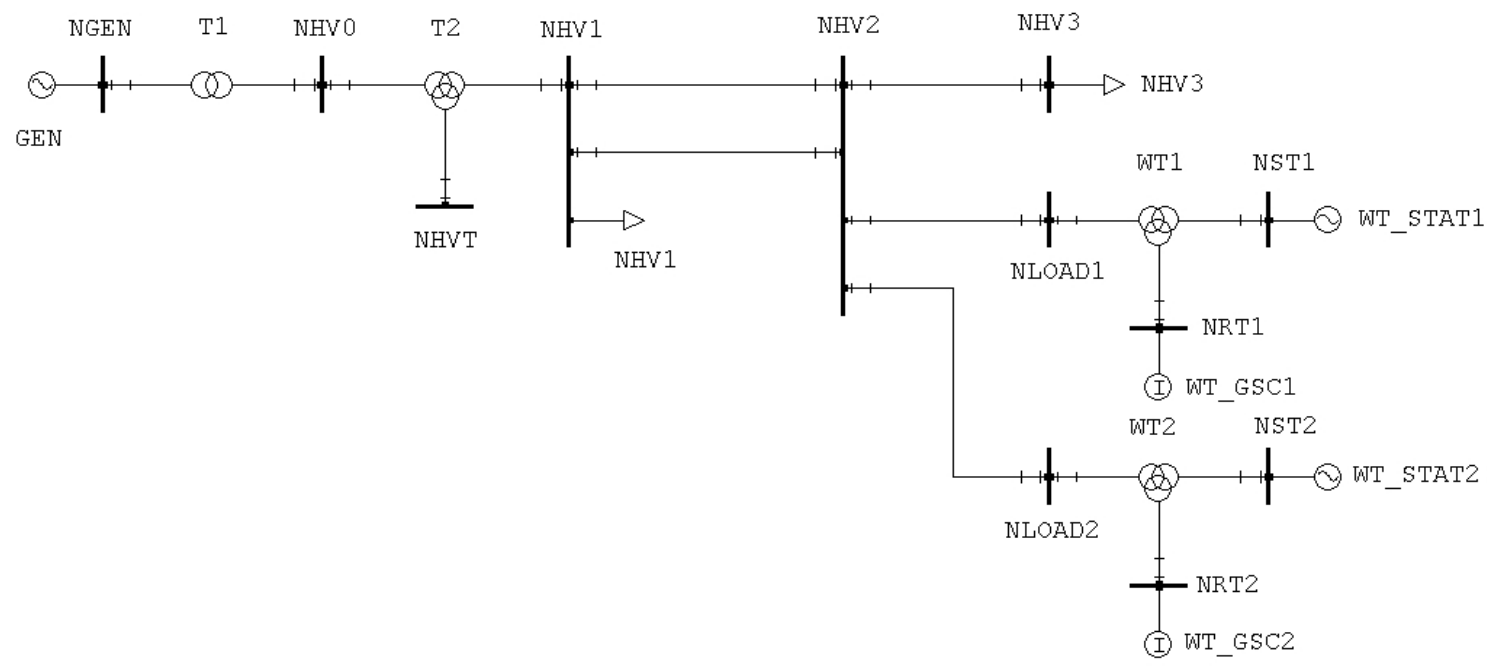

Figure 3. Overall view on the model of calculated electric power system

Case 1: DFIG stator protection device did not respond to this fault because a time delay of this device was set on $150 \mathrm{~ms}$. The voltage at node dropped during short circuit. Elimination of fault led to quick reconnection of power plant (Fig. 4).

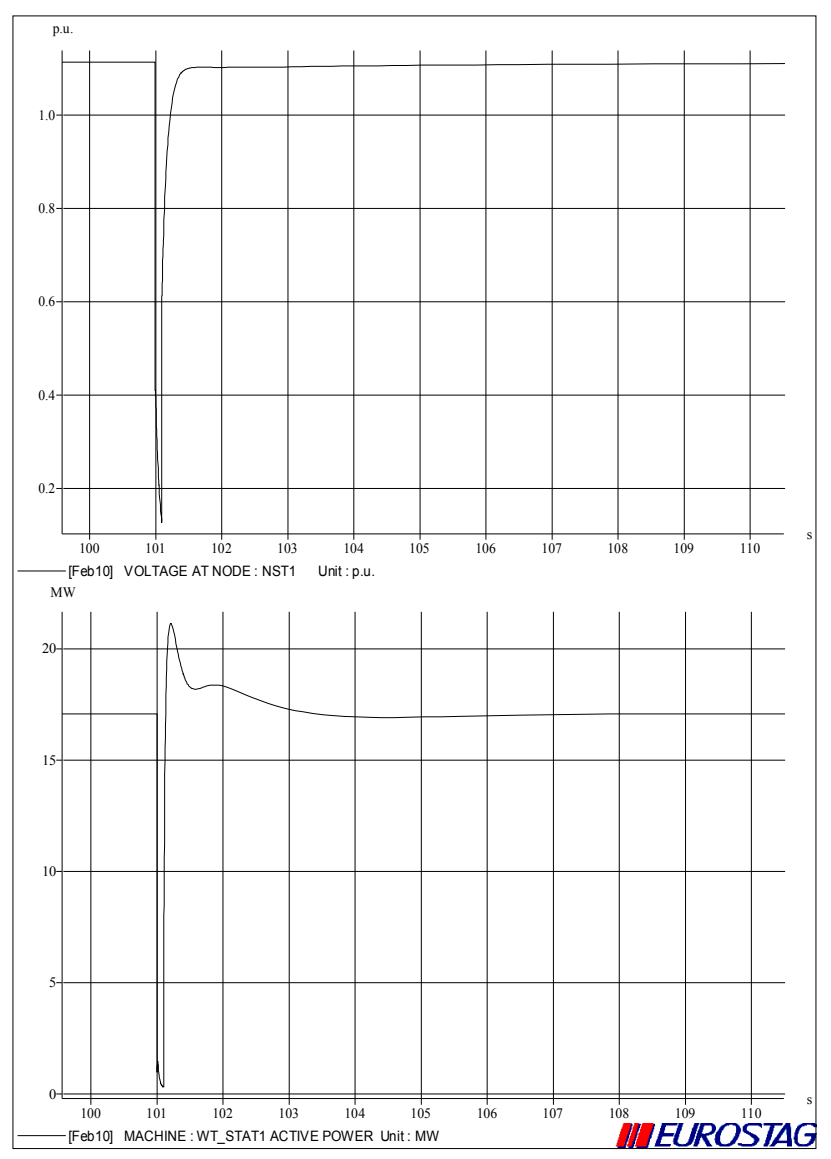

Figure 4. The evolution of the voltage at node NST1 and the active power produced by the WT STAT1
Case 2: DFIG stator protection device responded to this fault after $80 \mathrm{~ms}$ and power plant made slow reconnection. The slow reconnection solution brought the rotor to the synchronous speed and authorized the stator reconnection even if the voltage was not restored (Fig. 5).

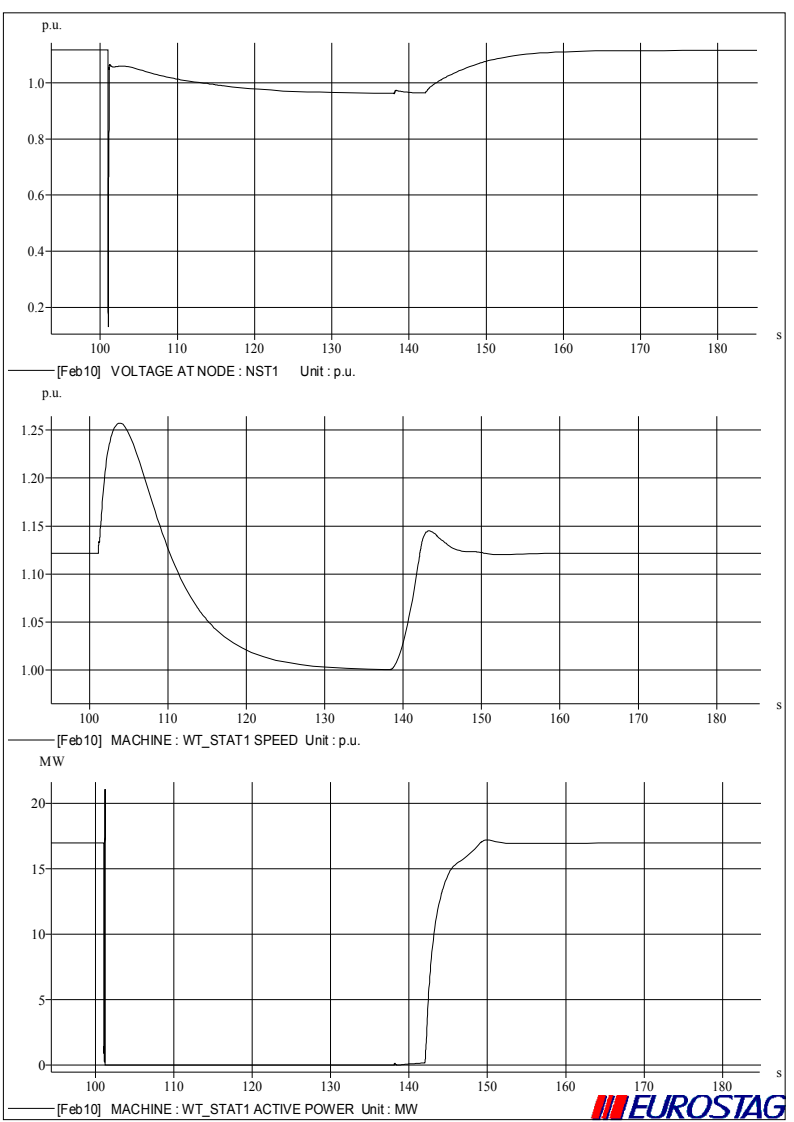

Figure 5. The evolution of the voltage at node NST1, the speed of the machine WT_STAT1 and the active power produced by the WT_STAT1 
Case 3: DFIG stator protection device responded to this fault after $80 \mathrm{~ms}$ and power plant made fast reconnection. The monitored variable was voltage at the stator connection node. This mode authorized the stator reconnection as soon as the voltage reached threshold 0.9 p.u. (Fig. 6).

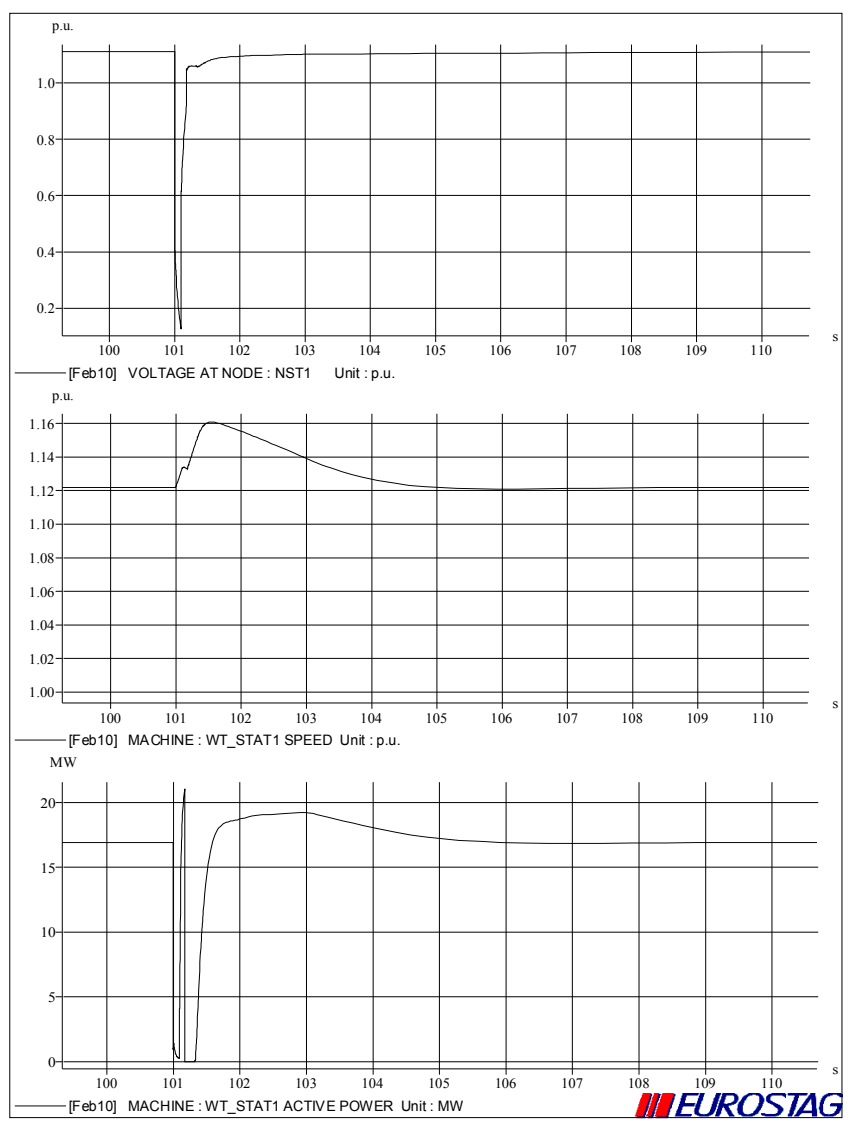

Figure 6. The evolution of the voltage at node NST1, the speed of the machine WT_STAT1 and the active power produced by the WT_STAT1

\section{CONCLUSION}

Wind power plants are one of the renewable electricity sources which have significant contribution in world energy production. Interest of investors in wind power plants installing is very intensive also in Slovakia (some GW), but centralized configuration of electrical network in not able to accept it.

Therefore it is necessary to exam impact of all distributed sources on system before their connection to the network to preserve reliability of EPS and quality of electricity [7], [8], [9], [10].

For this purposes it is very suitable to use EUROSTAG software which enables various studies, e.g.:

- Checking the keeping up of synchronism after various disturbances.

- Behaviour of the power system in emergency or in extreme conditions (voltage collapse, loss of synchronism, resynchronisation, etc...).
- Dynamic stability of the machines, regulations, transmission system around an operating point of the power system.

- Design, co-ordination and adjustment of protection systems for power plants and transmission networks.

Moreover, all those possibilities are available for balanced or unbalanced network conditions.

Results of modelling presented in this article correspond with theoretical knowledge and showed suitability of computer modelling of wind power plants operation in EUROSTAG software.

\section{ACKNOWLEDGMENT}

This work was supported by the Scientific Grant Agency of the Ministry of Education of Slovak Republic and the Slovak Academy of Sciences by the projects VEGA No. 1/0099/09 and No. 1/0166/10.

This work was supported by the Slovak Research and Development Agency under the contracts APVT-20-026902, APVV-0095-07, APVV-0385-07 and APVV SK-BG-0010-08.

The authors wish to thank for the support to the R\&D operational program Centre of excellence of power electronics systems and materials for their components. The project is funded by European Community, ERDF - European regional development fund.

\section{REFERENCES}

[1] M. Mešter, V. Chladný: Analýza elektrizačnej sústavy pomocou programu Eurostag. In: EE - Časopis pre elektrotechniku a energetiku, Vol. 11, No 5/S, October 2005. Bratislava, Slovakia, 2005, pp. 92-94. ISSN 1335-2547.

[2] Tractebel and Electricité de France: Eurostag - Tutorial, October 2002.

[3] J. Mihalíková: Problém výberu simulačného nástroja pre simulačný projekt. In: Novus scientia 2007, TU Košice, Slovakia, 2007, pp. 392396. ISBN 978-80-8073-922-5.

[4] K. Máslo: Modelování větrných elektráren pro výpočty dynamické stability. In: Obnovitelné zdroje a jejich začleňování do DS. Praha: EGU Praha Engineering, a.s., 2004.

[5] V. Akhmatov: Analysis of dynamic behaviour of electric power system with large amount of wind power: PhD Thesis. Technical University of Denmark, April 2003. 270 p.

[6] Z. Hruška, P. Trubač, K. Máslo, J. Rusnák, M. Hvizdoš: Chování větrných elektráren při přechodových dějích v sítích a jeho modelování. In: ČK CIRED 2009, Tábor, Czech Republic, 2009, 25 p. ISBN 978-80254-5635-4

[7] P. Braciník, S. Krollová: Predikcia výkonu veternej veternej elektrárne. In: EE - Časopis pre elektrotechniku a energetiku, Vol. 15, No. 2 - 3, 2009. Bratislava, Slovakia, 2009, pp. 21-24, pp. 22-24. ISSN 1335-2547.

[8] P. Baxant, P. Toman, J. Országhová: Distribuované řízení energetických zdroju. In: ENERGOMATIKA 2007, Praha, Czech Republic, 2007.

[9] J. Tůma, S. Rusek, Z. Martínek, I. Chemišinec, R. Goňo: Spolehlivost v elektroenergetice, ČVUT Praha, Czech Republic, 2006, ISBN 80-2396483-6.

[10] E. Dvorský, P. Hejtmánková, E. Ščerba, J. Škorpil: Modelling of PV Systems. In: Proceedings of ISES World Congress 2007, Springer Berlin, 2009. ISBN 9783540759973. 